\title{
Logos indicating environmental sustainability in wine production: An exploratory study on how do Burgundy wine consumers perceive them
} \author{
Sylvie Issanchou ${ }^{\mathrm{c}, \mathrm{d}, \mathrm{e}}$, Rosires Deliza ${ }^{\mathrm{g}, *, 1}$ \\ a Lab. for Experimentation in Social Sciences and Behavioral Analysis (LESSAC), Burgundy School of Business, F-21000 Dijon, France \\ b Departamento de Ciencia y Tecnología de Alimentos, Facultad de Química, Universidad de la República, Montevideo, Uruguay \\ c CNRS, UMR6265, Centre des Sciences du Goût et de l'Alimentation, F-21000 Dijon, France \\ ' UMR1324 Centre des Sciences du Goût et de l'Alimentation, F-21000 Dijon, France \\ e Université de Bourgogne, Centre des Sciences du Goût et de l'Alimentation, F-21000 Dijon, France \\ ${ }^{\mathrm{f}}$ Departamento de Alimentos, Faculdade de Farmácia, Universidade Federal de Minas Gerais, Belo Horizonte, MG, Brazil \\ ${ }^{g}$ Embrapa (Brazilian Agricultural Research Corporation) Food Technology, Rio de Janeiro, RJ, Brazil
}

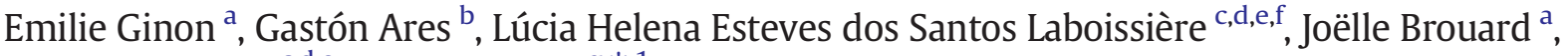

\section{A R T I C L E I N F O}

\section{Article history:}

Received 9 January 2014

Accepted 13 April 2014

Available online 29 April 2014

\section{Keywords:}

Consumer perception

Logos

Organic wine

Sustainability

Wine

\begin{abstract}
A B S T R A C T
Logos on environmental sustainability could consist of an effective strategy to provide consumers with accurate, understandable and trustworthy information to encourage them to buy environmentally sustainable wines. However, the large number of different logos indicating environmental sustainability available in the market raises the question of whether their associated messages are successfully conveyed to consumers. In this context, the aim of the present exploratory study was to investigate how Burgundy wine consumers perceive a series of logos indicating environmental sustainability in wine production.

Fourteen logos available in the French market were selected: three logos being specific to wine and eleven nonspecific. The logos were presented to 127 wine consumers from Dijon area (France), following an incomplete balanced block design. For each logo, participants had to answer the question: "What does a bottle of wine with this logo suggest to you?". Responses were qualitatively analyzed and grouped into different categories. Chi-square tests and Correspondence analysis were used to identify the relationship among logos and categories. Results showed large differences in how consumers perceived the logos. Biodyvin, the former European $\mathrm{AB}$ and the French $A B$ organic logos were the logos that most successfully conveyed their messages, being strongly associated to organic wine. Most logos did not communicate a message related to environmental sustainability, which reaffirms the need to provide consumers with adequate information on environmental sustainability and to conduct further research on this subject.
\end{abstract}

(c) 2014 Elsevier Ltd. All rights reserved.

\section{Introduction}

Reducing the use of pesticides in French agriculture has been highlighted as a major factor for preventing pollution (Ricci, 2010; Saint-Ges \& Bélis-Bergouignan, 2009). In this context, the French program Ecophyto, 2008 aims at achieving a 50\% reduction in pesticide use by 2018 (Aubertot et al., 2005; Ecophyto, 2008; Jacquet, Butault, \& Guichard, 2011). The sensitivity of grapevine to major pests and diseases justifies a high level of protection. The vine-growing sector is the second largest user of pesticides in France and accounts for $20 \%$ of the total consumption in volume. As a consequence, there is a strong

\footnotetext{
* Corresponding author at: Embrapa Agroindústria de Alimentos, Av. das Américas, 29501 CEP 23020-470 Rio de Janeiro, RJ, Brazil.

E-mail address: rosires.deliza@embrapa.br (R. Deliza).

1 The author Deliza was at Embrapa Labex Europe, INRA UMR CSGA, Dijon, France during the planning and data collection of this study.
}

need for French vine-growers to engage in more environmentally sustainable wine production practices (Aubertot et al., 2005; Rapport d'Information Sénat, 2012; Ricci, 2010; Saint-Ges \& Bélis-Bergouignan, 2009). Besides, traces of contaminants may be found in wine, which can reduce consumer interest in the product (ENDURE, 2010a,b; Kaushik, Satya, \& Naik, 2009).

One of the main challenges is to identify which incentives can be effective to encourage vine-growers to adopt environmentally friendly production practices. Taking into account that pesticides are regarded as low cost insurance for production, the use of arbitrary and restrictive regulations does not seem to be an appropriate long-term solution (Bazoche et al., 2014). Another possible alternative would be to sell environmentally friendly wine at a higher price, which could consist of an economic incentive for producers towards the adoption of production practices associated to the use of less pesticide. However, this approach requires consumers' willingness to pay a premium price for wine produced following environmentally sustainable production practices 
(Appleby, Costanigro, Thilmany, \& Menke, 2012; Forbes, Cohen, Cullen, Wratten, \& Fountain, 2009; Remaud, Chabin, \& Mueller, 2010). In order to achieve this reduction of pesticide use it is necessary to align consumers' and producers' interests (Ricci, 2010).

Different drivers, like environmental regulations, personal values, perceived improved product quality and increased demand for wine produced with environmentally friendly practices, have stimulated interest in the development of improved environmental practices among producers and consumers of wine (Forbes et al., 2009; Gabzdylova, Raffensperger, \& Castka, 2009; Marshall, Cordano, \& Silverman, 2005; Point, Tyedmers, \& Naugler, 2012).

During the past two decades there has been a dramatic increase in environmental consciousness worldwide, with consumers changing their behavior to incorporate environmental considerations into lifestyle and consumption choices (Barber, Taylor, \& Strick, 2005). Animal welfare and environmental issues such as food miles, food energy use, soil and water degradation, or types of farming practice are being increasingly included in their decisions (ENDURE, 2010c).

Environmental sustainability is a credence attribute since consumers cannot determine by themselves if a wine has been produced using environmentally sustainable practices. Instead, they have to rely on the information provided by producers or other organizations (Darby \& Karni, 1973; Jahn, Schramm, \& Spiller, 2005). For this reason, consumers can only choose to buy environmentally sustainable wine once they are provided with accurate, understandable and trustworthy information.

In this context, the inclusion of logos indicating environmental sustainability could provide an effective mechanism to inform consumers about environmentally friendly products. This information in combination with awareness and concern about environmental issues could help consumers make better choices when purchasing their products and lead them to buy environmentally sustainable products (Bazoche et al., 2014; Leire \& Thidell, 2005; Michaud, Llerena, \& Joly, 2012). The importance of logos has been stressed by Golan, Kuchler, Mitchell, Greene, and Jessup (2001), who reported that consumers inferred that a product is not environmentally sustainable in the absence of a logo.

In the wine production industry, there are several competing ecolabels related to eco-certification, including organic certification and biodynamic certification (Delmas \& Gergaud, 2012). The large number of different logos indicating environmental sustainability available in the market raises the question as to whether their associated messages are successfully conveyed to consumers.

The present work is part of a larger project, ${ }^{2}$ which aims to investigate producers' willingness to produce environmentally friendly wine, as well as consumers' willingness to buy such wine. This project is focused on Burgundy, a French region well known for its high-quality wines.

Therefore, the aim of the present work was to investigate how Burgundy wine consumers perceive a series of logos indicating environmental sustainability in wine production.

\section{Materials and methods}

Consumers' perception of logos indicating environmental sustainability in wine production was studied using an open-ended question. This qualitative technique is less structured than quantitative approaches, allowing deeper probing of consumer behavior (Lawless \& Heymann, 2010). The open-ended question was the first part of a

\footnotetext{
2 VINPEST Project "An experimental investigation of the willingness to produce environmentally friendly wine" composed of two research axes addressing the following questions: Which incentives can be used to make wine producers engage in more environmentally friendly practices? And: Which incentives can be used to motivate wine consumers to value environmentally friendly practices in wine producing?
}

larger questionnaire, which comprised questions related to wine and wine consumption, environmental behavior, and demographic data.

\subsection{Participants}

A convenient sample of 127 participants from Dijon area (France) took part in the study. They were selected from the ChemoSens Platform's PanelSens database ${ }^{3}$ in January 2011. The recruitment criteria included men and women who purchased and consumed wine at least occasionally. Participants were recruited according to three age groups: 20 to 35,36 to 50 , and 51 to 70 years old, balanced for gender. Before starting the study consumers were explained about the general aim of the research. They've read and signed an informed consent form.

\section{2. $\log 0 \mathrm{~S}$}

Twenty-two logos were identified in the French market, from which 14 were used in this study, as shown in Table 1.

Twelve logos related to environmental sustainability were selected according to the following criteria: available on French wine bottles in the French market and delivered by public or non-public organizations at the French or European level.

Among these twelve selected logos three were specific to wine and delivered by French non-public organizations (TerraVitis, Biodyvin, Vignerons en développement durable). Nine were non-specific to wine, among them two were delivered by French public organizations (French $A B$, Haute valeur environnementale), three were delivered by French non-public organizations (AgriConfiance, L'abeille sentinelle d'environnement, NF Environnement), two were delivered by European public organizations (former European $A B$, new European $A B$ ) and two by European non-public organizations (Demeter, Nature et Progrès).

In France there are three main levels of environmentally friendly production practices related to wine: integrated, organic and biodynamic. Integrated production practices propose an optimal combination of chemical and biological controls of pests (Stockdale et al., 2001). The logos TerraVitis, Vignerons en dèveloppement durable, AgriConfiance, and NF Environnement are associated to integrated production. Organic production is characterized by the avoidance of mineral fertilizers and synthetic pesticides (Lotter, 2003). The logos Nature et Progrès, French $A B$, former European $A B$ and new European $A B$ are linked to the organic level of environmental sustainability. Biodynamic production considers a holistic approach to the exploitation of natural resources. Apart from avoiding the use of fertilizers and pesticides, this production practice seeks to minimize the use of fossil fuels by implementing artisanal operations (Koepff, 1981). The logos Biodyvin and Demeter refer to biodynamic production practices.

In addition, two other logos related to the origin of wine were used as references for participants: the French logo for controlled designation of origin $(A O C)$ and the French version of the European logo for protected designation of origin $(A O P)$.

\subsection{Data collection}

Different sessions were organized in January 2011 at the Centre des Sciences du Goût et de l'Alimentation (CSGA) in Dijon, France. An average of 10 people participated in each session, which lasted 50-60 min. Participants arrived at CSGA following a pre-established schedule. They were invited to come to the Sensory Lab and received some instructions about the test they were about to perform. Participants signed an informed consent form and received $10 €$ for their participation.

\footnotetext{
${ }^{3}$ This database has been declared to the relevant authority (Commission Nationale Informatique et Libertés - CNIL $-\mathrm{n}^{\circ}$ d'autorisation 1148039).
} 
Table 1

Characteristics of the $14 \operatorname{logos}^{\mathrm{a}}$ used in the experiment

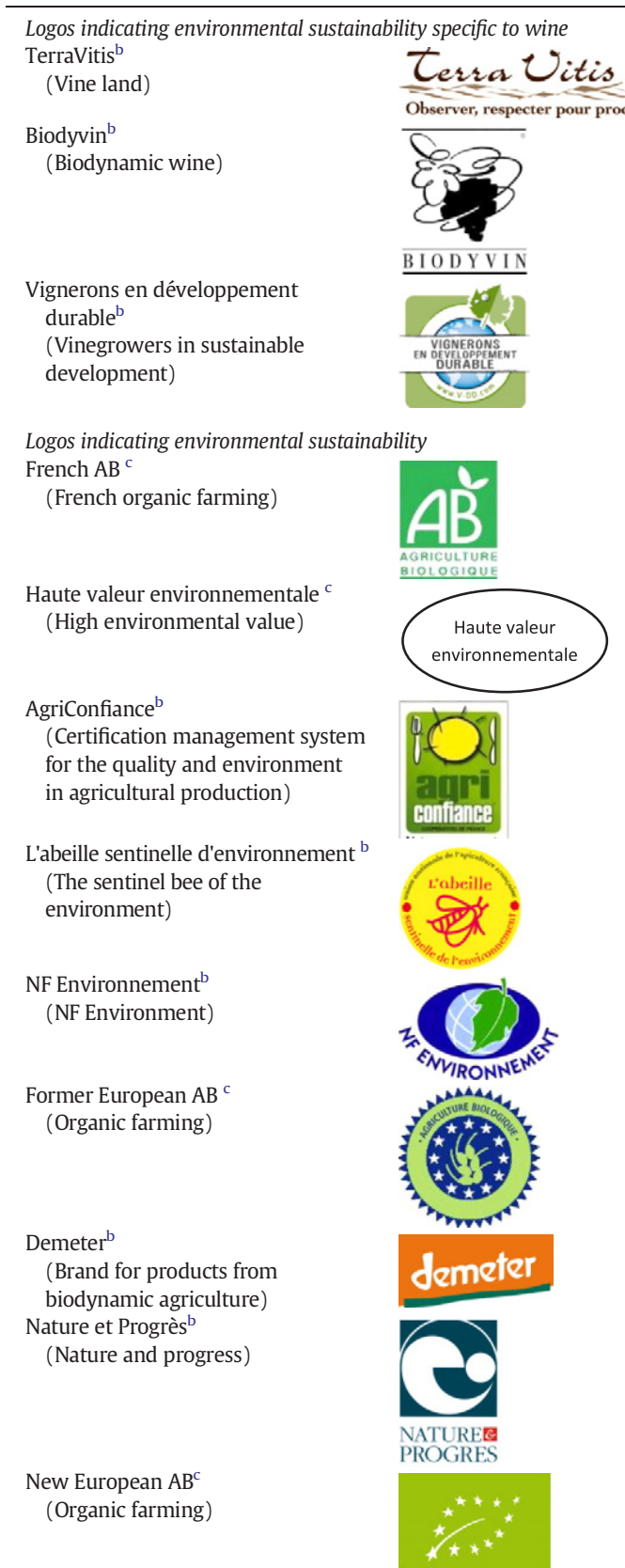

Protected designation of origin (PDO)

AOC (Appellation d'origine contrôllée $)^{\mathrm{c}}$

(Controlled designation of origin)

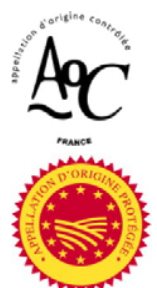

AOP (Appellation d'órigine protégée $)^{\mathrm{c}}$ (Protected designation of origin)

\footnotetext{
a The terms between brackets were translated to English.

b Non-public organization with their own standards.

c Public regulation.
}

Participants completed a questionnaire with several questions Among them there was one that asked participants to look at each logo and answer the following open-ended question: "What does a bottle of wine with this logo suggest to you?". To avoid saturation due to the large number of investigated logos only seven were evaluated by each participant. Logos were presented following a balanced incomplete design (Williams' Latin Square).

\subsection{Data analysis}

Data were analyzed by grouping the responses into exclusive and exhaustive categories (Krippendorff, 2004). The phrases and words elicited by participants were coded by triangulation (Modell, 2005). First, a search for recurrent terms within each logo was performed, and terms with similar meaning were grouped into categories. The classification was performed by triangulation (Guerrero et al., 2010). Accordingly, three different researchers with previous experience in content analysis evaluated the data. Results presented in the current paper were obtained by a consensus between the three researchers to balance out their subjective influence (Denzin, 1978).

Frequency of mention of each category for each logo was determined by counting the number of participants who used the words or phrases included in the category, for that particular logo. Categories mentioned by more than $5 \%$ of the participants for at least one logo were considered for further analysis (Guerrero et al., 2010; Vidal, Ares, \& Giménez, 2013).

Chi-square tests were performed to evaluate significant differences in participant perception of logos. Subsequently, a chi-square per cell analysis was conducted to identify the source of variation of the Global Chi-square (Symoneaux, Galmarini, \& Mehinagic, 2012). Correspondence analysis was used to get a bi-dimensional representation of logos and the relationship among logos and categories. Hierarchical cluster analysis was carried out on sample coordinates in the first four dimensions of the Correspondence analysis to identify groups of logos that were similarly perceived by participants. Euclidean distances and Ward's aggregation criterion were considered.

All statistical analyses were performed using XLStat 2009 (Addinsoft, Paris).

\section{Results}

One hundred and fifty participants from Dijon area (France) were invited to take part in this study and 127 turned up. Table 2 shows the

Table 2

Socio-demographic characteristics of participants $(n=127)$.

\begin{tabular}{lc}
\hline & Participants (\%) \\
\hline Gender & 54 \\
Female & 46 \\
Male & 32 \\
Age (years) & 32 \\
20-35 (average: 27.9) & 36 \\
$36-50$ (average: 41.9) & \\
$51-70$ (average: 60.5$)$ & 6 \\
Education & 17 \\
No study certificate & 18 \\
Secondary school & 27 \\
High school & 23 \\
College & 9 \\
Master & \\
PhD & 32 \\
Number of adults in the household & 58 \\
1 & 10 \\
2 & \\
3 or more & 76 \\
Number of children (less than 18 years old) living at home & 24 \\
0 & \\
1 or more & 43 \\
Wine consumption frequency & 38 \\
Less than once a week & 11 \\
Once or twice a week & 8 \\
Almost everyday & \\
Everyday & \\
\hline
\end{tabular}


socio-demographic characteristics of the final sample. It should be noted that $59 \%$ of the sample had high education level and the sample comprised mainly couples or single people with no children living at home. In relation to wine consumption frequency, $57 \%$ of the participants drank wine at least once or twice a week.

The responses provided by participants were highly heterogeneous, ranging from the use of chemical products and pesticides to sensory and hedonic associations. An overview of some of the responses elicited by participants is shown in Table 3. Individual responses were grouped into categories, from which 37 categories were mentioned by more than $5 \%$ of the participants (i.e., $n=4$ due to the incomplete design) for at least one logo. These categories comprised the great majority of the information elicited by participants since the responses that were not captured by coding were mentioned by less than four participants and were mostly unique responses.

The frequency in which the 37 selected categories were elicited for different logos significantly differed $\left(\chi^{2}=3071, \mathrm{p}<0.00001\right)$, implying large differences in how participants perceived them. As shown in Table 3, at the aggregate level, the most frequently mentioned categories were Organic wine, Environment, Unknown, and Compliance with standards. It should be noted that the category Environment is composed of terms that refer to the protection of the environment (fauna or flora), without specific reference to wine or to chemicals. The high number of categories with a low frequency of quotations showed that participants had very different perceptions of the evaluated logos. These categories were mostly related to quality, production type, wine origin and type, marketing strategies, authenticity, price, and sensory characteristics.

As shown in Table 4, Chi-square per cell test showed that significant differences $(\mathrm{p}<0.05)$ among logos existed for all categories considered in the analysis.

Logos for controlled and protected designation of origin ( $A O C$ and $A O P$, respectively) were neither associated to the categories Environment nor to Organic wine. These logos were linked to the categories Compliance with standards, Protected/delimited region or terroir, and Authentic. The $A O C$ logo was also significantly associated to the categories Better quality, Confidence and French wine; whereas the AOP logo was linked to the categories Agriculture, Controlled grape variety and Protected vine.

As shown in Table 4, the logos that most successfully conveyed messages related to environmental sustainability were Biodyvin, the former European $A B$ and the French $A B$ logos. They were strongly associated to the category Organic wine; whereas the last two were also linked to the category Without chemical products/additives. According to Burgundy participants, the environmentally sustainable dimension regarding wine production practices was mainly linked to the categories Organic wine, composed of terms like organic wine, production with minimum human intervention and treatment, reasoned culture, healthy agriculture/production, and the category Without chemical products/ additives, with terms such as without chemical products, without

Table 3

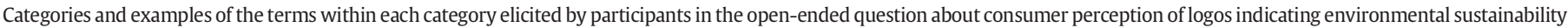
in wine production.

\begin{tabular}{|c|c|c|}
\hline Category & Examples of individual responses & $\begin{array}{l}\text { Number of } \\
\text { mentions }\end{array}$ \\
\hline Organic wine & $\begin{array}{l}\text { Organic wine, production with minimum human intervention and treatment, reasoned culture, healthy agriculture/production, } \\
\text { biological wine }\end{array}$ & 187 \\
\hline Environment & Protection of fauna/flora, no pollution, ecology & 180 \\
\hline Unknown & Unknown, nothing & 165 \\
\hline Compliance with standards & $\begin{array}{l}\text { Legal name, controlled wine, French standard, controlled production condition, traceability, monitored quality/quality control, } \\
\text { wine protected by a label }\end{array}$ & 107 \\
\hline Protected/delimited region or terroir & $\begin{array}{l}\text { Specific area/well defined geographic area, typical product of its area, protection of a local or regional heritage, protected } \\
\text { designation of origin }\end{array}$ & 75 \\
\hline Without chemical products/additives & Without chemical products, without chemical additives, less pesticide & 73 \\
\hline Better quality & Culture of quality, gustative quality, wine which will never be changed on its production level, higher quality & 72 \\
\hline European wine & European wine, exportation inside European Economic Community countries & 59 \\
\hline Natural & Natural & 36 \\
\hline Confidence & Confidence, reassurance, safety, known origin, reliable origin, serious, trust & 32 \\
\hline Cooperative & Society, group of producers, association of producers & 26 \\
\hline Agriculture & Agriculture & 20 \\
\hline Lack of confidence & No confidence, false organic wine (misleading advertising), no guarantee of organic wine, unknown origin, not natural, fraud & 19 \\
\hline Honey & Wine with honey taste/aromatic note of honey, wine flavored with honey, a honey-based wine, produced by the bees & 17 \\
\hline Healthy & Good for health, health, healthy wine & 15 \\
\hline Not adequate for wine & Not adapted to wine/not related to wine & 14 \\
\hline Marketing & Marketing, Store origin, less up to date than $\mathrm{AB}$ & 14 \\
\hline Artisanal production & Artisanal production/small producer, no industrial production, small producer, no handmade transformation & 13 \\
\hline Traditional & Respect for the traditional/conventional methods, tradition, expertise, respect for the wine culture & 13 \\
\hline Beekeeper & Beekeeper, agreement with a beekeeper, beekeeper close to the vine & 12 \\
\hline Authentic & Authenticity, wine less adulterated, not falsified, not copied & 12 \\
\hline Table wine & Table wine, regular wine & 11 \\
\hline Low quality & Poor quality, questionable quality, low quality, ugly, mixture of wines & 11 \\
\hline No guarantee of quality & No guarantee of quality & 10 \\
\hline Insect/Bee protection & Protection of insects/bees, not harmful to insects, protection of the bees, pollination in a natural way & 10 \\
\hline Expensive & Expensive, more expensive & 9 \\
\hline Recognized & Official, well-known, recognized & 9 \\
\hline Controlled grape variety & Wine name and grape variety controlled, protected type of wine, protected area/protected vine & 9 \\
\hline Rejection to buy/try & Rejection to buy, not attractive, not interesting, do not want to try & 9 \\
\hline Protected vine & Protected vine & 9 \\
\hline French wine & French wine & 9 \\
\hline Novel technology & New experimentation, new technology & 8 \\
\hline Discounted wine & Discounted wine, first price wine, cheap & 7 \\
\hline Surprising & Surprising/amazing, eye catching & 4 \\
\hline Fruity or sweet wine & Sweet wine, fruity wine & 4 \\
\hline Solidarity economy & Solidarity among producers, solidarity economy, fair price to the vine growers & 4 \\
\hline Wine from a store brand & Young commercial wine, wine produced by Giant Casino, large trader & 4 \\
\hline
\end{tabular}


Table 4

Number of mentions per logo of each category elicited by participants in the open-ended question about consumer perception of logos indicating environmental sustainability in wine production and results of the Chi-square per cell test.

\begin{tabular}{|c|c|c|c|c|c|c|c|c|c|c|c|c|c|c|}
\hline \multirow[t]{2}{*}{ Category } & \multirow{2}{*}{$\begin{array}{l}\mathrm{AOC} \\
\overline{(n=65)}\end{array}$} & \multirow{2}{*}{$\begin{array}{l}\text { AOP } \\
\overline{(n=63)}\end{array}$} & \multirow{2}{*}{$\begin{array}{l}\text { Former } \\
\text { European } A B \\
(\mathrm{n}=71)\end{array}$} & \multirow{2}{*}{$\begin{array}{l}\text { New } \\
\text { European } A B \\
(n=66)\end{array}$} & \multirow{2}{*}{$\begin{array}{l}\text { French } A B \\
\overline{(n=65)} \\
\end{array}$} & \multirow{2}{*}{$\begin{array}{l}\text { L'abeille sentinelle } \\
\text { d'environnement } \\
(\mathrm{n}=65)\end{array}$} & \multirow{2}{*}{$\begin{array}{l}\text { AgriConfiance } \\
(n=66)\end{array}$} & \multirow{2}{*}{$\begin{array}{l}\text { Biodyvin } \\
\overline{(n=64)}\end{array}$} & \multirow{2}{*}{$\begin{array}{l}\text { Demeter } \\
\overline{(\mathrm{n}=64)} \\
\end{array}$} & \multirow{2}{*}{$\begin{array}{l}\text { Haute valeur } \\
\text { environnementale }\end{array}$} & \multirow{2}{*}{$\begin{array}{l}\text { Nature et } \\
\text { Progrès } \\
(\mathrm{n}=66) \\
\end{array}$} & \multirow{2}{*}{$\begin{array}{l}\text { NF Environnement } \\
\overline{(n=64)}\end{array}$} & \multirow{2}{*}{$\begin{array}{l}\text { TerraVitis } \\
\overline{(n=62)} \\
\end{array}$} & \multirow{2}{*}{$\begin{array}{l}\begin{array}{l}\text { Vignerons en } \\
\text { développement } \\
\text { durable }\end{array} \\
(\mathrm{n}=62) \\
\end{array}$} \\
\hline & & & & & & & & & & & & & & \\
\hline Organic wine & $0(-)^{* * *}$ & $3(-)^{* *}$ & $38(+)^{* * * *}$ & 13 & $41(+)^{* * * *}$ & $2(-)^{* * * *}$ & 12 & $42(+)^{* * *}$ & 6 & $2(-)^{* *}$ & 9 & $5(-)^{* *}$ & $7(-)^{*}$ & 7 \\
\hline Environment & $0(-)^{* * *}$ & $4(-)^{* *}$ & $3(-)^{* *}$ & 10 & $5(-)^{* *}$ & $21(+) *$ & $4(-)^{* *}$ & $0(-)^{* * *}$ & $1(-)^{* * *}$ & $25(+)^{* * * *}$ & 16 & $36(+)^{* * *}$ & 19 & $36(+) * * *$ \\
\hline Unknown & $4(-)^{* *}$ & 7 & $4(-)^{* *}$ & 18 & $0(-)^{* * *}$ & $4(-)^{* * *}$ & 9 & 12 & $34(+)^{* * *}$ & $29(+)^{* * *}$ & $22(+)^{* * *}$ & $4(-)^{* *}$ & 11 & 7 \\
\hline $\begin{array}{l}\text { Compliance with } \\
\text { standards }\end{array}$ & $20(+)^{* * * *}$ & $13(+)^{*}$ & 6 & 3 & 11 & $1(-)^{* * *}$ & 8 & 3 & 3 & 2 & $0(-)^{* *}$ & $31(+)^{* * *}$ & $2(-)^{*}$ & 4 \\
\hline $\begin{array}{l}\text { Protected/delimited } \\
\text { region or terroir }\end{array}$ & $32(+)^{* * *}$ & $18(+)^{* * *}$ & $0(-)^{*}$ & $0(-)^{*}$ & $0(-)^{* *}$ & 2 & 3 & $0(-)^{*}$ & $0(-)^{*}$ & 3 & 1 & $1(-)^{*}$ & $14(+)^{* * *}$ & 1 \\
\hline $\begin{array}{l}\text { Without chemical } \\
\text { products/additives }\end{array}$ & $0(-)^{* *}$ & $0(-)^{*}$ & $19(+)^{* * *}$ & $0(-)^{*}$ & $22(+)^{* * *}$ & 9 & 2 & 4 & $0(-)^{*}$ & 6 & 2 & 2 & 4 & 3 \\
\hline Better quality & $19(+)^{* * *}$ & 7 & 3 & $1(-)^{*}$ & 7 & 3 & $11(+)^{* *}$ & 4 & $0(-)^{*}$ & $0(-)^{*}$ & 2 & 4 & 5 & 6 \\
\hline European wine & 1 & 7 & $11(+)^{* * * *}$ & $39(+)^{* * *}$ & $0(-)^{*}$ & $0(-)^{*}$ & $0(-)^{*}$ & $0(-)^{*}$ & $0(-)^{*}$ & $0(-)^{*}$ & 0 & $0(-)^{*}$ & 1 & $0(-)^{*}$ \\
\hline Natural & 2 & 0 & 1 & $9(+)^{* * *}$ & 6 & 4 & 2 & 1 & 0 & 0 & 3 & 3 & 5 & 0 \\
\hline Confidence & $15(+)^{* * * *}$ & 5 & 1 & 0 & 2 & 2 & 5 & 0 & 0 & 0 & 0 & 1 & 0 & 1 \\
\hline Cooperative & 0 & 0 & 0 & 0 & 0 & 0 & $17(+)^{* * *}$ & 1 & 1 & 0 & 0 & 1 & 1 & $5(+)^{* *}$ \\
\hline Agriculture & 0 & $4(+)^{*}$ & 0 & 1 & 0 & 0 & 0 & $5(+)^{* *}$ & 3 & 0 & 0 & 2 & $5(+)^{* * *}$ & 0 \\
\hline Lack of confidence & 0 & 0 & 0 & 1 & 0 & 0 & 0 & 3 & 2 & $7(+)^{* * *}$ & $6(+)^{* * *}$ & 0 & 0 & 0 \\
\hline Honey & 0 & 0 & 0 & 0 & 0 & $17(+)^{* * *}$ & 0 & 0 & 0 & 0 & 0 & 0 & 0 & 0 \\
\hline Healthy & 0 & 0 & $4(+)^{* *}$ & 0 & 2 & 1 & 2 & 2 & 0 & 0 & 0 & 1 & 0 & $3(+)^{*}$ \\
\hline Not adequate for wine & 0 & 0 & 0 & 0 & 0 & $8(+)^{* * *}$ & 0 & 0 & $5(+)^{* * *}$ & 0 & 0 & 0 & 1 & 0 \\
\hline Marketing & 0 & 0 & 1 & 0 & 1 & 0 & 1 & $4(+)^{* *}$ & 1 & 0 & 2 & 1 & $3(+)^{*}$ & 0 \\
\hline Artisanal production & 1 & 2 & 0 & 0 & 0 & 0 & $6(+)^{* * * *}$ & 0 & 0 & 0 & 1 & 0 & $3(+)^{*}$ & 0 \\
\hline Traditional & 1 & 0 & 0 & 0 & 0 & 1 & 1 & 0 & 0 & 0 & 1 & 0 & $8(+)^{* * * *}$ & 1 \\
\hline Beekeeper & 0 & 0 & $3(+) *$ & 0 & 0 & $9(+)^{* * *}$ & 0 & 0 & 0 & 0 & 0 & 0 & 0 & 0 \\
\hline Authentic & $3(+) *$ & $6(+)^{* * * *}$ & 0 & 0 & 0 & 0 & 1 & 1 & 0 & 0 & 0 & 0 & 1 & 0 \\
\hline Table wine & 1 & 0 & 0 & 0 & 0 & 0 & $3(+)^{*}$ & 2 & $4(+)^{* * *}$ & 1 & 0 & 0 & 0 & 0 \\
\hline Low quality & 0 & 0 & 1 & 0 & $3(+)^{*}$ & 0 & 1 & 1 & $4(+)^{* * *}$ & 1 & 0 & 0 & 0 & 0 \\
\hline No guarantee of quality & 0 & 0 & 0 & 1 & 1 & 0 & $3(+)^{* *}$ & 0 & 0 & 0 & 1 & 2 & 2 & 0 \\
\hline Insect/Bee protection & 0 & 0 & 0 & 0 & 0 & $10(+)^{* * *}$ & 0 & 0 & 0 & 0 & 0 & 0 & 0 & 0 \\
\hline Expensive & 0 & 0 & 0 & 0 & $3(+)^{* *}$ & 0 & 0 & 2 & $2(+) *$ & 0 & 0 & 1 & 1 & 0 \\
\hline Recognized & 2 & 0 & 1 & 0 & $4(+)^{* * * *}$ & 0 & 0 & 0 & 0 & 0 & 1 & 1 & 0 & 0 \\
\hline Controlled grape variety & 0 & $9(+)^{* * *}$ & 0 & 0 & 0 & 0 & 0 & 0 & 0 & 0 & 0 & 0 & 0 & 0 \\
\hline Rejection to buy/try & 1 & 0 & 0 & 0 & 0 & 0 & $3(+)^{* *}$ & 1 & $2(+)^{*}$ & 0 & 0 & 2 & 0 & 0 \\
\hline Protected vine & 2 & $5(+)^{* * *}$ & 0 & 0 & 0 & 0 & 0 & 0 & 0 & 0 & 0 & 0 & 2 & 0 \\
\hline French wine & $7(+)^{* * *}$ & 0 & 0 & 0 & 0 & 0 & 0 & 0 & 0 & 0 & 0 & 2 & 0 & 0 \\
\hline Novel technology & 0 & 0 & 0 & 0 & 0 & 0 & 0 & 0 & 0 & 0 & $8(+)^{* * * *}$ & 0 & 0 & 0 \\
\hline Discounted wine & 0 & 0 & 0 & 1 & 0 & 0 & 1 & 0 & $5(+)^{* * * *}$ & 0 & 0 & 0 & 0 & 0 \\
\hline Surprising & 0 & 0 & 0 & 0 & 0 & $3(+)^{* * *}$ & 0 & 0 & 0 & 1 & 0 & 0 & 0 & 0 \\
\hline Fruity or sweet wine & 0 & 1 & 0 & 0 & 0 & $3(+)^{* * *}$ & 0 & 0 & 0 & 0 & 0 & 0 & 0 & 0 \\
\hline Solidarity economy & 0 & 0 & 0 & 0 & 0 & 0 & 0 & 0 & 0 & 0 & 0 & 0 & 0 & $4(+)^{* * *}$ \\
\hline Wine from a store brand & 0 & 0 & 0 & 0 & 0 & 0 & 0 & 0 & $4(+)^{* * * *}$ & 0 & 0 & 0 & 0 & 0 \\
\hline
\end{tabular}

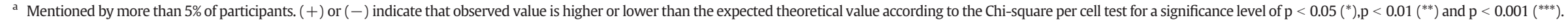


chemical additives, and less pesticides (Table 3). Biodyvin was also linked to the categories Agriculture and Marketing, and the former European $A B$ to the categories European wine and Healthy.

$N F$ Environnement, Vignerons en dèveloppement durable, Haute valeur environnementale (HVE) and, to a lesser extent, L'abeille sentinelle d'environnement were associated to the category Environment. NF Environnement was also related to Compliance with standards, whereas Vignerons en dèveloppement durable was associated to Solidarity economy, Cooperative and Healthy. The logo L'abeille sentinelle d'environnement conveyed messages related to Honey, Sweet or fruity wines, Protection of insects and bees, and Beekeepers, but was also regarded as Not adequate for wine, Environment and Surprising.

Most logos did not communicate a message related to environmental sustainability. Demeter, Haute valeur environnementale, and Nature et Progrès were significantly perceived as Unknown by a high percentage of participants (between 34\% and 53\%). Furthermore, the new European $A B$ logo was associated to Natural, and most participants associated it with a wine produced within the European Union (61\%). In addition, some of these logos were negatively perceived by participants. Demeter also conveyed some negative associations related to low quality wine, being significantly linked to the categories Not adequate for wine, Table wine, Low quality, Discounted wine, Rejection to buy/try, Expensive
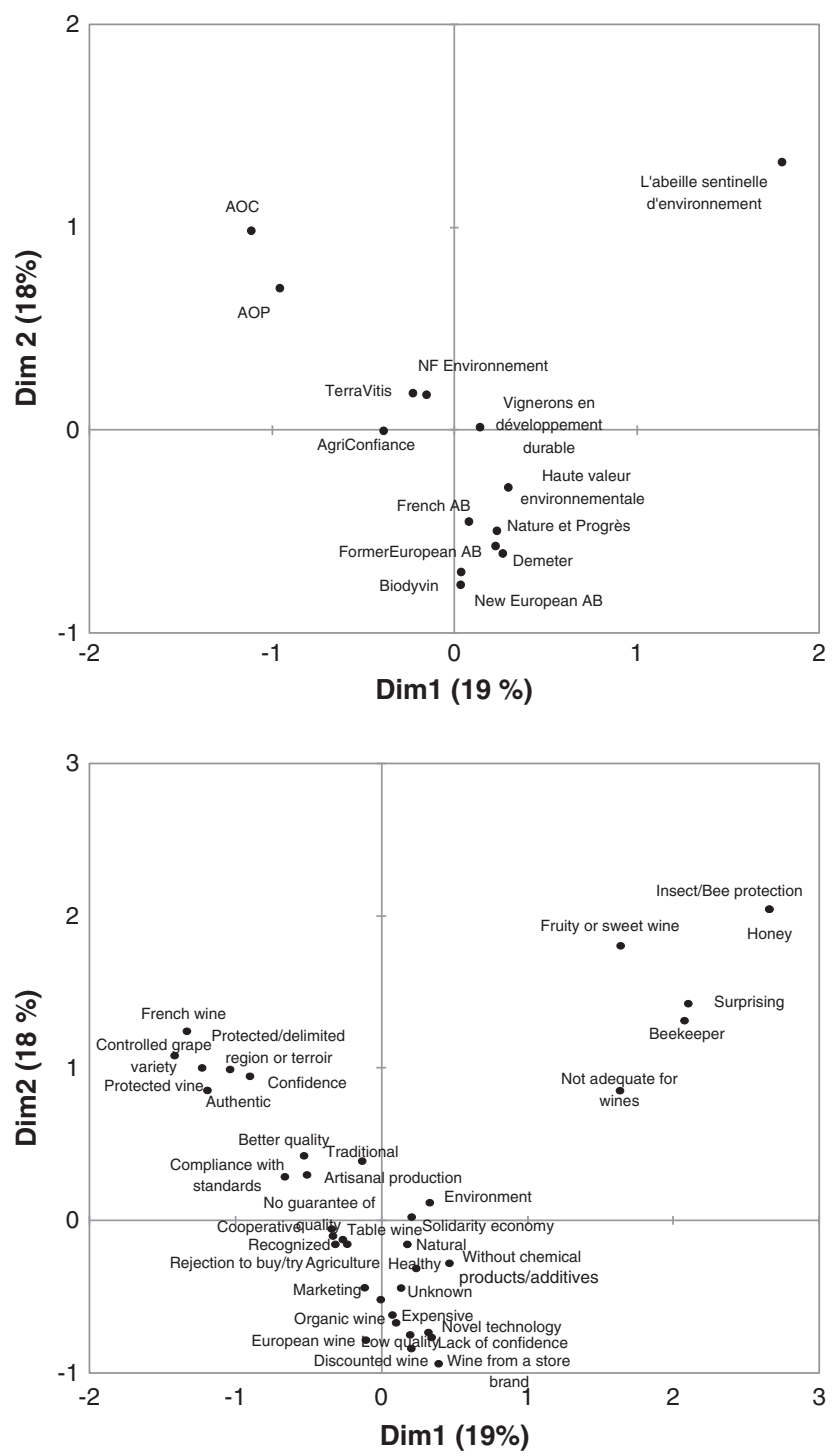

and Wine from a store brand. Haute valeur environnementale and Nature et Progrès logos were significantly linked to the category Lack of confidence. The latter logo was also related to Novel technologies.

The AgriConfiance logo was associated to categories Cooperative and Better quality wine; whereas the TerraVitis logo was linked to Protected/ delimited region or terroir, Agriculture, Marketing, Artisanal production, and Traditional.

The above mentioned results are summarized in the representation of logos and categories in the first four dimensions of the Correspondence analysis performed on the frequency table of participants' responses (Fig. 1). The first four dimensions of the Correspondence analysis accounted for by $62 \%$ of the inertia of the experimental data, which is reasonable considering the large number of logos and categories considered in the analysis (Lê, 2014).

According to Hierarchical cluster analysis, the logos were sorted into six main groups, as shown in Fig. 2. L'abeille sentinelle d'environnement (the sentinel bee of the environment) was clearly differentiated from all other logos, being associated to Insect/bee protection and to Honey and Fruity or Sweet wine. The AOC and AOP logos were also perceived differently from the rest, as expected, since they referred to wine origin. The new European $A B$ logo was sorted in a separate group from the former European $A B$ and the French $A B \log o$, being associated to wine
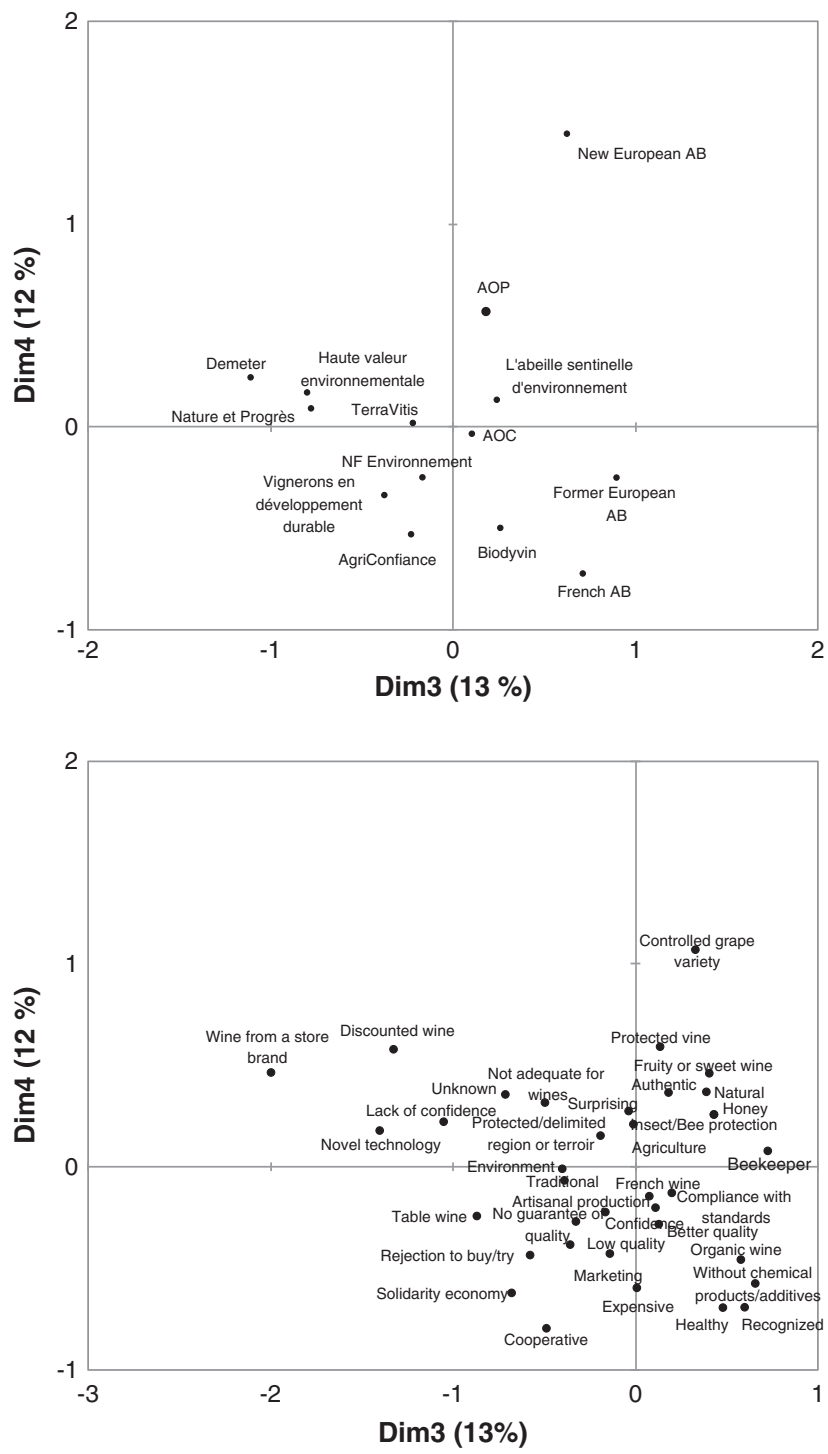

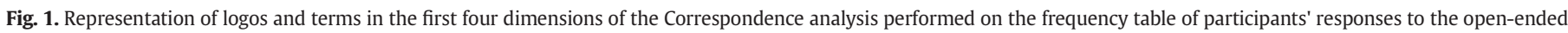
question about consumer perception of logos indicating environmental sustainability in wine production. 


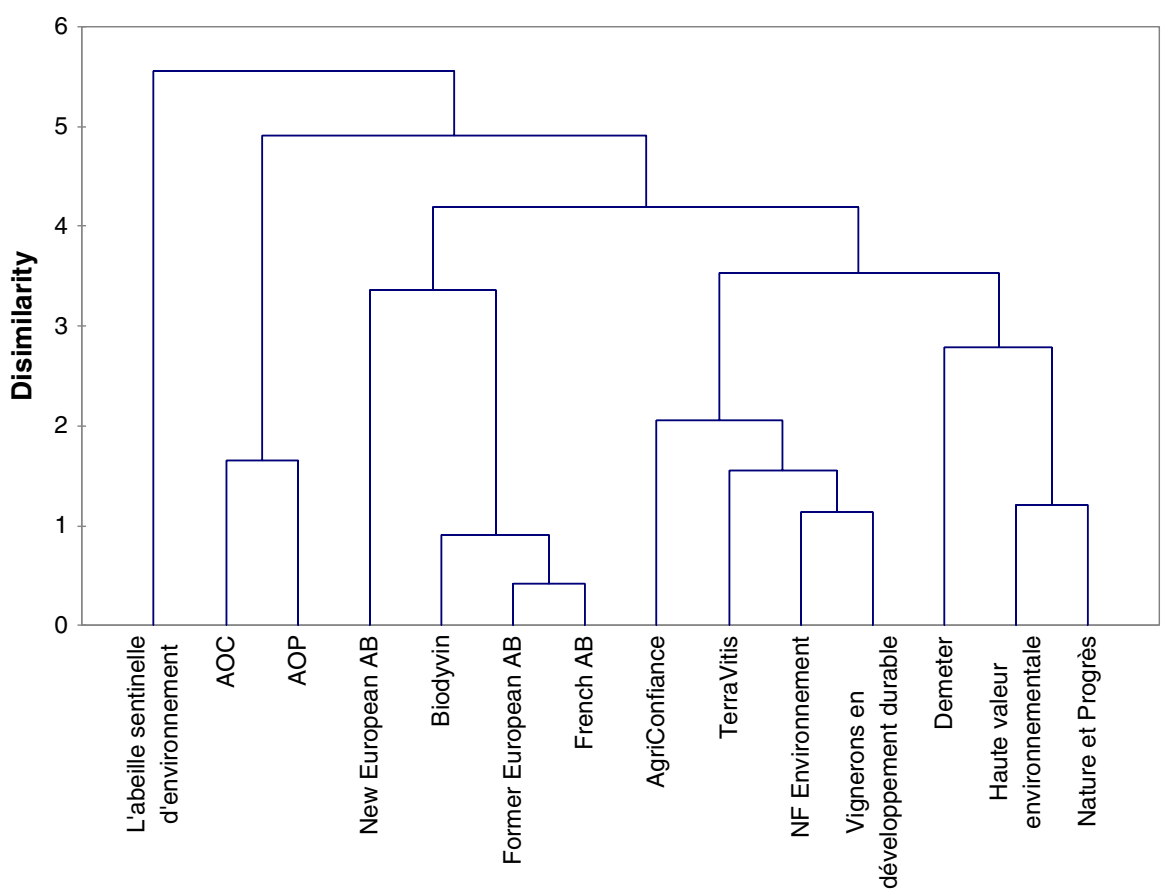

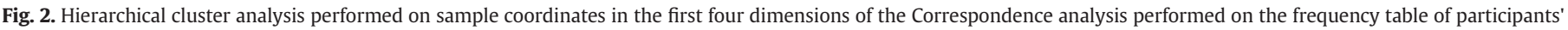
responses to the open-ended question about consumer perception of logos indicating environmental sustainability in wine production.

origin instead of environmental sustainability. The fourth group of logos was composed of Biodyvin, the former European $A B$ and the French $A B$ logos, which were the only ones that successfully conveyed a message related to environmental sustainability, according to Burgundy participants. AgriConfiance, TerraVitis, NF Environnement and Vignerons en dèveloppement durable were similarly perceived by participants and were not significantly related to environmental sustainability. Finally, the last group of logos was composed of Demeter, Haute valeur environnementale, and Nature et Progrès, which were considered Unknown by the majority of participants, and mainly raised significant negative associations, mainly related to low quality wines and lack of confidence.

\section{Discussion}

Among the 12 logos related to environmentally sustainable practices, only two (former European $A B$ and French $A B$ (organic)) appeared well known and correctly understood. The result concerning the French $A B$ (organic) is in agreement with Marette, Messéan, and Millet (2012), who reported that this logo is well known and dominates the segment of environmentally friendly products in France. It must be pointed out that, at the time of the present study, the new European $A B$ logo was quite unknown, as it had been used since July 2010, and neither related to environmental sustainability nor to Organic wine. This suggests that this new logo was not yet familiar for Burgundy wine consumers at the time of the data collection. Among the three specific logos to wine on environmental sustainability, Biodyvin appeared less unknown and well associated to the category Organic wine. However, this association could be due to the fact that the term 'bio' mentioned on the graphical design of the logo, as 'Bio' refers to 'biologique' in French, which, means organic. In this sense, it is important to stress that Biodyvin indicates biodynamic wine production, suggesting that consumers are not aware of the difference between environmental sustainable practices. This possibility is supported by the fact that Biodyvin was not linked to the idea of reduced use of chemical products, additives, or pesticides for the participants of this study.

Results from the present study suggest that only the former European $A B$ and the French $A B$ logos might successfully convey a message related to the reduced use of pesticides and chemicals. Results concerning the new European $A B$ logo suggest that participants are not aware of its meaning. Janssen and Hamm (2011) stated that the new mandatory European Union logo has not been successful in building consumer trust yet and that other public and non-public certification schemes were clearly more trustworthy.

Among the three logos indicating environmental sustainability specific to wine, the TerraVitis logo was not related to environmental sustainability but was strongly associated to wine origin, particularly to traditional wines, produced in a Protected/delimited region or terroir. Bazoche, Deola, and Soler (2008) reported that wines with this logo were less valued than conventional ones, which could be attributed to participants' lack of familiarity with the meaning of the TerraVitis logo. The other logo specific to wine (Vignerons en dèveloppement durable) raised significant associations related to the categories Environment, Cooperative and Healthy, but was not specifically linked to the adoption of environmentally sustainable production practices or to the reduced use of pesticides or chemical products/additives.

Additionally, it should be highlighted that many logos, such as $A O C, A O P$, former European $A B$, French $A B$, Biodyvin, Demeter, and AgriConfiance did not raise associations related to the category Environment, while others like Haute valeur environnementale, $N F$ Environnement, Vignerons en dèveloppement durable and L'abeille sentinelle d'environnement were strongly linked to this category by Burgundy participants (Table 4). This result suggests that the inclusion of terms related to the environment on the design of these last four logos induced participants to make an association with the aforementioned category. Overall, results underlined the importance of the term mentioned on the design of the labels. For example, the logo L'abeille sentinelle d'environnement was associated with words related to Honey, and to a lesser extent the logo Nature et Progrès was associated to the category Novel technology. The importance of the terms included in design of the logos is also revealed by the fact that the European $A B$ logos (former and new) evoked associations related to Europe, due to the presence of the stars. In particular, the new European $A B \log$ o was associated with European wines but not organic production, while it was mentioned for the former European $A B \log$, probably due to the fact that it was more familiar for participants (Table 4). 
When no specific cue related to the meaning was included on the logo, a wide range of non-consensual associations was identified. In this sense, Larceneux, Benoit-Moreau, and Renaudin (2012) recommended to improve labels' ability to convey their message by reducing their complexity and polysemy, i.e. its ability to generate multiple associations in the consumers' mind.

Overall, the present study revealed that Burgundy consumers lacked of knowledge regarding logos indicating environmental sustainability. In fact, participants' perception of the logos was strongly induced by the signs and terms included in their graphical design. Results are in accordance with previous data reporting that consumers' perception of organic certification logos is mainly subjective and in many cases is not based on objective data (Janssen \& Hamm, 2012).

A logo always refers to specifications and implies that control is undertaken to check that these specifications are compiled with. So, a logo should be associated to a certain level of trust. The extent to which eco-labels increase green consumption is highly dependent on their trustworthiness (Bruce \& Laroiya, 2007; Lavallee \& Plouffe, 2004; Sonderskov \& Daugbjerg, 2011). Trust in organic logos and certification schemes have been reported to be a key point for increasing consumer willingness to purchase organic products (Albersmeier, Schulze, \& Spiller, 2010; Golan et al., 2001; Jahn et al., 2005). Consumers are usually willing to pay premium prices for logos that are well known and trustworthy, with perceived strict organic standards and a strict control system (Janssen \& Hamm, 2012). However, in the present work the $A O C$ logo was the only one among the fourteen, which was significantly linked to the category Confidence. Among the 12 logos related to environmentally sustainable practices, both HVE and Nature et Progrès were strongly associated to the category Lack of confidence, while AgriConfiance was significantly related to the category No guarantee of quality and Demeter to the category Low quality.

The large number of different logos indicating environmental sustainability available in the market certainly seems to create confusion among consumers and probably contributes to the reduced credibility of several logs, in agreement with the results reported by Timonen, Heiskanen, Kärnä, and Niva (1998) and Leire and Thidell (2005).

\section{Conclusions}

This paper focused on investigating how Burgundy wine participants perceived twelve logos indicating environmental sustainability. Although a considerable number of respondents participated in this qualitative study, it is important to highlight that all of them were Burgundy wine consumers. Thus, extending conclusions on the identified associations to the French population as a whole should be done with care. Nevertheless, Burgundy is a wine production area where pesticide use is common in relation to the frequency of pests due to the climate. Consequently, one can speculate that Burgundy participants should be particularly concerned about environmental issues, although similar studies have not been carried out in other regions of France to investigate this hypothesis.

Results revealed that only two out of the twelve logos were known and successfully conveyed a message related to environmental sustainability. Results from this qualitative exploratory study reaffirmed the need to provide consumers with adequate information (message conveyed by logos) on environmental sustainability and indicate the need for further research on this subject. The importance of having a logo with a clear meaning, which could be easily understood by consumers, was observed from this study.

Consumers cannot directly evaluate environmental sustainability by themselves and are only able to choose to purchase environmentally sustainable wine once they are provided with accurate, understandable and trustworthy information. Thus, there is an urgent need for those organizations owning a labeling scheme related to environmental sustainability in wine production to improve their design information and communication strategies to help consumers make better choices while shopping for wines.

It would be interesting to investigate if education qualification level, wine involvement or interest in environmental issues affects consumers' understanding of logos indicating environmental sustainability.

\section{Acknowledgments}

This study is part of the Vinpest project "An experimental investigation of the willingness to produce environmentally friendly wine" supported by the French Ministry of Ecology, Sustainable Development and Energy. This study was also funded by the Regional Council of Burgundy. The authors thank Embrapa (Brazilian Agricultural Research Corporation) Labex Europe for the financial support. Lúcia H.E.S. Laboissière acknowledges CNPq (Brazilian Council for Scientific and Technological Development)/Labex for her postdoctoral fellowship. We also thank Mrs. Fabienne Boulliot from the ChemoSens platform (CSGA) and Miss Stephanie Ravassod for participant recruitment.

\section{References}

Albersmeier, F., Schulze, H., \& Spiller, A. (2010). System dynamics in food quality certifications: Development of an audit integrity system. International Journal of Food System Dynamics, 2010(1), 69-81.

Appleby, C., Costanigro, M., Thilmany, D., \& Menke, S. (2012). Measuring consumer willingness to pay for low-sulfite wine: A conjoint analysis. AAWE Working Paper No. 117. American Association of Wine Economists.

Aubertot, J. N., Barbier, J. M., Carpentier, A., Gril, J. J., Guichard, L., Lucas, P., et al. (2005) Pesticides, agriculture et environnement. Réduire l'utilisation des pesticides et limiter leurs impacts environnementauxExpertise scientifique collective, synthèse du rapport INRA et Cemagref (64 pp.).

Barber, N., Taylor, C., \& Strick, S. (2005). Wine consumers' environmental knowledge and attitudes: Influence on willingness to purchase. International Journal of Wine Research, 1, 59-72.

Bazoche, P., Combris, P., Giraud-Héraud, E., Seabra Pinto, A., Bunte, F., \& Tsakiridou, E. (2014). Willingness to pay for pesticide reduction in the EU: Nothing but organic? European Review of Agricultural Economics, 41(1), 87-109.

Bazoche, P., Deola, C., \& Soler, L. G. (2008). An experimental study of wine consumers' willingness to pay for environmental characteristics. 12th Congress of the European Association of Agricultural Economists - EAAE. Brussels, Belgium.

Bruce, C., \& Laroiya, A. (2007). The production of eco-labels. Environmental \& Resource Economics, 36, 275-293.

Darby, M., \& Karni, E. (1973). Free competition and the optimal amount of fraud. Journal of Law and Economics, 16, 67-88.

Delmas, M.A., \& Gergaud, O. (2012). Sustainable certification for future generations: The case of the wine industry. AAWE Working Paper No. 121. American Association of Wine Economists.

Denzin, N. K. (1978). The research act: A theoretical introduction to sociological methods. New York: McGraw-Hill Inc.

Ecophyto (2008, September 10). Plan for the reduction of pesticide use over the period 2008-2018. The Ecophyto Plan.

ENDURE (2010a). European network for durable exploitation of crop protection strategies: Integrated pest management in Europe. INRA (132 pp.).

ENDURE (2010, Julyb). European network for durable exploitation of crop protection strategies deliverable DR1.23. Pesticide use in viticulture: Available data on current practices and innovations, bottlenecks and needs for research in this field and specific leaflets analysing the conditions of adoption of some innovations. INRA (35 pp.).

ENDURE (2010, Aprilc). European network for durable exploitation of crop protection strategies. European crop protection in 2030: A foresight study. INRA (82 pp.).

Forbes, S., Cohen, D. A., Cullen, R., Wratten, S. D., \& Fountain, J. (2009). Consumer attitudes regarding environmentally sustainable wine: An exploratory study of the New Zealand marketplace. Journal of Cleaner Production, 17(13), 1195-1199.

Gabzdylova, B., Raffensperger, J. F., \& Castka, P. (2009). Sustainability in the New Zealand wine industry: Drivers, stakeholders and practices. Journal of Cleaner Production, 17(11), 992-998.

Golan, E., Kuchler, F., Mitchell, L., Greene, C., \& Jessup, A. (2001). Economics of food labeling. Journal of Consumer Policy, 24(2), 117-184.

Guerrero, L., Claret, A., Verbeke, W., Enderli, G., Zakowska-Biemans, S., Vanhonacker, F., et al. (2010). Perception of traditional food products in six European regions using free word association. Food Quality and Preference, 21, 225-233.

Jacquet, F., Butault, J. -P., \& Guichard, L. (2011). An economic analysis of the possibility of reducing pesticides in French field crops. Ecological Economics, 70(9), 1638-1648.

Jahn, G., Schramm, M., \& Spiller, A. (2005). The reliability of certification: Quality labels as a consumer policy tool. Journal of Consumer Policy, 28(1), 53-73.

Janssen, M., \& Hamm, U. (2011). Consumer perception of different organic certification schemes in five European countries. Organic Agriculture, 1, 31-43.

Janssen, M., \& Hamm, U. (2012). Product labelling in the market for organic food: Consumer preferences and willingness-to-pay for different organic certification logos. Food Quality and Preference, 25, 9-22. 
Kaushik, G., Satya, S., \& Naik, S. N. (2009). Food processing a tool to pesticide residue dissipation - A review. Food Research International, 42, 26-40.

Koepff, H. H. (1981). The principles and practices of biodynamic agriculture. In B. Stonehouse (Ed.), Biological husbandry - A scientific approach to organic farming (pp. 237.250). London: Butterworths.

Krippendorff, K. (2004). Content analysis: An introduction to its methodology (2nd ed.). Thousand Oaks, CA: Sage Publications.

Larceneux, F., Benoit-Moreau, F., \& Renaudin, V. (2012). Why might organic labels fail to influence consumer choices? Marginal labelling and brand equity effects. Journal of Consumer Policy, 35(1), 85-104.

Lavallée, S., \& Plouffe, S. (2004). The ecolabel and sustainable development. International Journal of Life Cycle Assessment, 9(6), 349-354.

Lawless, H. T., \& Heymann, H. (2010). Sensory evaluation of food Principles and practices (2nd ed.). New York: Springer, 379-400.

Lê, S. (2014). Introduction to multivariate statistical techniques for sensory characterization. In P. Varela, \& G. Ares (Eds.), Novel techniques in sensory characterization and consumer profiling (pp. 41-83). Boca Raton: CRC Press.

Leire, C., \& Thidell, A. (2005). Product-related environmental information to guide consumer purchases - A review and analysis of research on perceptions, understanding and use among Nordic consumers. Journal of Cleaner Production, 13(10-11), 1061-1070.

Lotter, D. W. (2003). Organic agriculture. Journal of Sustainable Agriculture, 21, 59-128.

Marette, S., Messéan, A., \& Millet, G. (2012). Consumers' willingness to pay for ecofriendly apples under different labels: Evidences from a lab experiment. Food Policy, 37(2), 151-161.

Marshall, R. S., Cordano, M., \& Silverman, M. (2005). Exploring individual and institutiona drivers of proactive environmentalism in the US wine industry. Business Strategy and the Environment, 14, 92-109.

Michaud, C., Llerena, D., \& Joly, I. (2012). Willingness to pay for environmental attributes of non-agricultural products: A real choice experiment. European Review of Agricultural Economics Advance, 20, 2012, http://dx.doi.org/10.1093/erae/jbs025 (access published July).
Modell, S. (2005). Triangulation between case study and survey methods in management accounting research: An assessment of validity implications. Management Accounting Research, 16, 231-254.

Point, E., Tyedmers, P., \& Naugler, C. (2012). Life cycle environmental impacts of wine production and consumption in Nova Scotia, Canada. Journal of Cleaner Production, 27, 11-20.

Rapport d'Information Sénat (2012, Octobre 10). Mission commune d'information sur les pesticides et leur impact sur la santé et l'environnement. (No42, Tome 1).

Remaud, H., Chabin, Y., \& Mueller, S. (2010). Do consumers value sustainable wine claims? An international comparison. 33rd World Congress of Vine and Wine, 20-27 June, Tbilisi, Georgia.

Ricci, P. (2010). Economiser en pesticides: contrainte ou opportunité? Innovations Agronomiques, 8, 1-13.

Saint-Ges, V., \& Bélis-Bergouignan, M. -C. (2009). Ways of reducing pesticides use in Bordeaux vineyards. Journal of Cleaner Production, 17(18), 1644-1653.

Sonderskov, K. M., \& Daugbjerg, C. (2011). The state and consumer confidence in eco-labeling: Organic labeling in Denmark, Sweden, The United Kingdom and The United States. Agriculture and Human Values, 28, 507-517.

Stockdale, E. A., Lampkin, N. H., Hovi, M., Keatinge, R., Lennartsson, E. K. M., Macdonald, D. W., et al. (2001). Agronomic and environmental implications of organic farming systems. Advances in Agronomy, 70, 261-327.

Symoneaux, R. Galmarini, M. V. \& Mehinagic, E. (2012). Comment analysis of consumer's likes and dislikes as an alternative tool to preference mapping. A case study on apples. Food Quality and Preference, 24, 59-66.

Timonen, P., Heiskanen, E., Kärnä, A., \& Niva, M. (1998). Improving the environmental quality of products: The views of actors in the product chain. Finland: National Consumer Research Centre.

Vidal, L., Ares, G., \& Giménez, A. (2013). Projective techniques to uncover consumer perception: Application of three methodologies to ready-to-eat salads. Food Quality and Preference, 28, 1-7. 